Role of agricultural engineering in environmental and sustainable development

for the valley and delta areas: $1308-1326$

\title{
METHANE PRODUCTION BY ANAEROBIC DIGESTION FROM CATTLE DUNG AND CHICKEN MANURE UNDER LABORATORY CONDITIONS
}

\author{
A. S. El-Sayed"; T. A. Mehana ${ }^{* *}$; M. A. Abdel-Hadi* \\ and A. M. Mustafa*
}

\section{ABSTRACT}

Laboratory-scale digesters were constructed to investigate the effect of digester shape (horizontal and vertical) and substrate type, cattle dung $(C D)$, chicken manure $(C M)$ as mono-digestion and a mixture of them $(50 \% \mathrm{CD}+50 \% \mathrm{CM}, w / w)$ as co-digestion on quantity and quality of biogas produced. The experimental work was carried out at $20 \pm 3{ }^{\circ} \mathrm{C}$ (winter season), $29 \pm 3{ }^{\circ} \mathrm{C}$ (summer season) and $38 \pm 1{ }^{\circ} \mathrm{C}$ (heating treatment) through digestion period of 60 days.

The results showed that, the highest value methane $68.1 \%$ (by volume) was obtained from the vertical digester of fed with $C D+C M$ at summer temperature. On the contrary, the lowest value of methane $42.0 \%$ was obtained in the horizontal digesters fed with CM alone under heating temperature. The highest value of specific methane production rate of 238 $L \mathrm{~kg}^{-1} V S$ added per day was obtained from the horizontal digesters fed with CD+CM at summer temperature, while the lowest rate of $32 \mathrm{~L} \mathrm{~kg}^{-1} V S$ added per day was observed in the horizontal digesters fed with CM alone under heating temperature.

\section{INTRODUCTION}

The yearly wet manure production from cattle; chickens, ducks and turkeys are about 11 million-ton in Egypt (FAO, 2001). The 1 anaerobic digestion for treatment of organic wastes and biogas

*Prof., Associate Prof. and Demonstrator of Agric. Eng., Agric. Eng. Dept., Fac. of Agric., Suez Canal Univ.

*** Prof. of Soil Microbiology and Biochemistry, Soil and Water Dept., Fac. of Agric., Suez Canal Univ. 
production is an environmentally attractive technology. It has environmental benefits including providing an indigenous and renewable energy source, reducing air pollution, reducing water pollution, combining organic waste treatment with recycling of plant nutrients and improving the fertilizer quality of farm manures, thus increasing the substitution of chemical fertilizers (Tafdrup, 1995).

The cattle dung is the most suitable material for biogas plants because of the methane producing bacteria already contained in the stomach of ruminants. However the specific gas production is lower and the proportion of $\mathrm{CH}_{4}$ is around 65\% because of pre-fermentation in the stomach (GTZ, 1999) and the average $\mathrm{CH}_{4}$ yield of $0.20-0.25 \mathrm{~m}^{3} \mathrm{~kg}^{-1} \mathrm{VS}$ added (Hartmann et al., 2000). Whereas the higher nitrogen content of poultry wastes as compared to manures from other farm animals make them difficult substrate for anaerobic digestion (Salminen and Rintala, 2002 a). Ammonia produced in protein degradation may cause problems in anaerobic digestion as unionized ammonia inhibits anaerobic microorganisms, particularly methanogenes (Angelidaki and Ahring, 1993). Therefore, the co-digestion of poultry wastes with dairy manure provides the necessary nutrients and buffer capacity and proved to be very successful way for improving biogas production (Weiland, 2000).

Lusk (1999) stated that, the plug-flow digesters usually operate within the mesophilic temperature range, with a hydraulic retention time (HRT) of 20 to 30 days, depending on characteristics of the waste and operating temperature. Sanchez et al. (2000) studied the effect of temperature and $\mathrm{pH}$ on the kinetics of $\mathrm{CH}_{4}$ production in the batch anaerobic digestion of cattle manure. They found that the methane yield decreased when temperature was increased from 35 to $60{ }^{\circ} \mathrm{C}$ at values of 7.0 and $7.6 \mathrm{pH}$. The methaneproducing bacteria live best under neutral to slightly alkaline conditions, which have different optimal $\mathrm{pH}$ ranges. Methanogenic archea can function in quite narrow $\mathrm{pH}$ interval from 5.5 to 8.5 with an optimal range of 6.5-8.0 (Nielsen, 2006).

Anaerobic digestion microorganisms utilize carbon 25-30 times faster than nitrogen. Thus to meet this requirement, microbes need a 20 to $30: 1$ ratio of $\mathrm{C}$ to $\mathrm{N}$ with the largest percentage of the carbon being readily degradable 
(Bardiya and Gaur, 1997). Zennaki et al. (1996) stated that, the ordinarily 7-9\% TS concentration is best-suite.

The objective of this study is to investigate the effect of digester shape and substrate type on biogas production under different digestion temperatures.

\section{MATERIALS AND METHODS}

\subsection{Bench-scale biogas digester}

Horizontal and vertical cylindrical biogas digesters were constructed in the work shop of the Agricultural Engineering Department, Faculty of Agriculture, Suez Canal University to investigate the experimental parameters under study. Schematic diagram of horizontal and vertical biogas digesters are shown in Fig (1).

Each digester was fabricated from galvanized steel sheet of $1.5 \mathrm{~mm}$ thickness, $450 \mathrm{~mm}$ long and $250 \mathrm{~mm}$ diameter with total capacity of 22 liters and digestion volume of 17 liters. It has inlet and outlet tube for feeding by organic wastes and rejecting the digested materials. To follow up the digestion processes, the digester was provided by two orifices, one to release the produced gas and another for the $\mathrm{pH}$-temperatures measurements. The heating unit consists of electrical water heater with supplement thermostatic electrical heater and suction pump 90-Watt motor assembled with an insulated water tank. The form of heating unit beside the close cycle serpentine is shown in Fig. (1).

\subsection{Substrates}

Cattle dung (CD) and chicken manure (CM) were taken from the Research Farm of Agriculture Faculty, Suez-Canal University. Table (1) illustrates chemical analysis of raw chicken manure and cattle dung. 
3- Pressure balance chamber

5- Biogas

7- Gas outlet

9- Suction pump
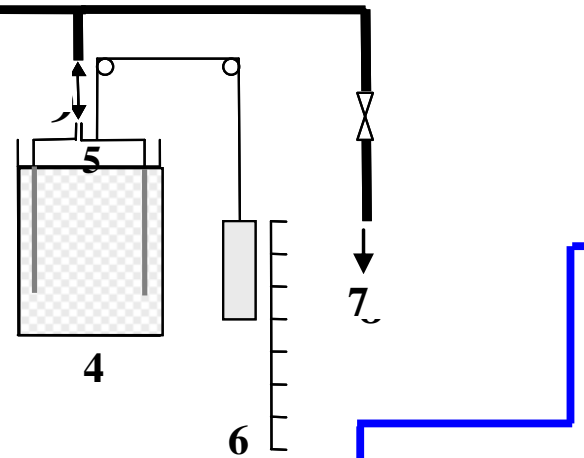

$\underline{3}$

6
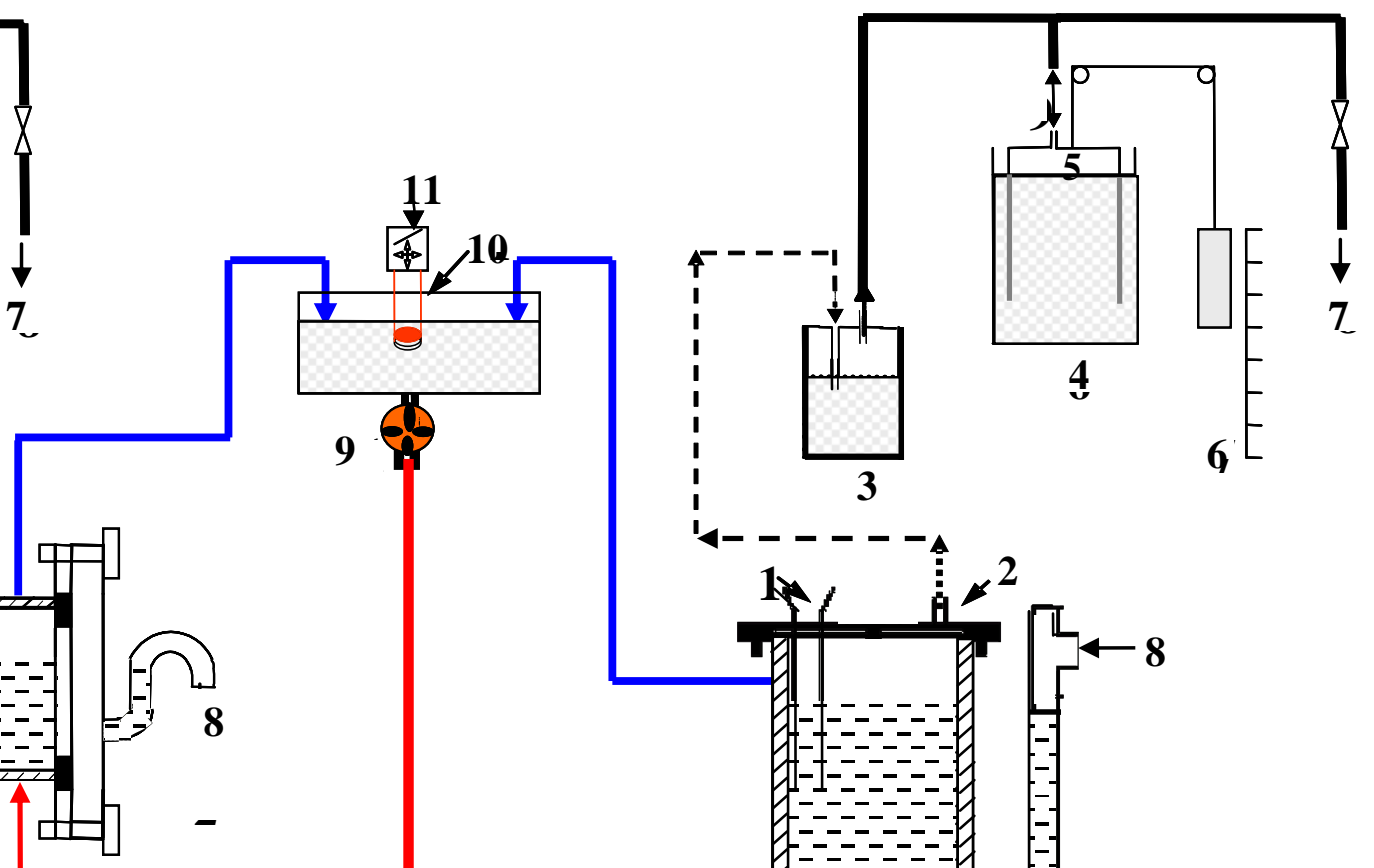

11- Thermostat

Fig. (1): Schematic diagram of the horizontal and vertical bench-scale biogas digester. 
Table (1): Chemical analysis of raw cattle dung and chicken manure

\begin{tabular}{lcc}
\hline Chemical analysis & Cattle dung (CD) & Chicken manure (CM) \\
\hline $\mathrm{pH}^{*}$ & 8.34 & 8.01 \\
Total solids (TS), \% & 17.3 & 21.7 \\
Volatile solids (VS), \% & 12.1 & 13.1 \\
Volatile solids, \% as TS & 69.9 & 60.2 \\
Ash, \% as TS & 30.1 & 39.8 \\
Organic carbon dry, \% & 40.5 & 34.9 \\
Total nitrogen, \% & 1.95 & 4.10 \\
C:N ratio & $20.8: 1$ & $8.51: 1$ \\
Carbohydrate, \% (d. TS) & 50.18 & 23.7 \\
Raw protein, \% (d. TS) & 12.2 & 25.6 \\
Raw fat, \% (d. TS) & 7.52 & 10.9 \\
\hline
\end{tabular}

* In manure-water suspension (1:2.5)

The calculation of the total solids (TS \%) of cattle dung and chicken manure were $17.3 \%$ and $21.7 \%$, respectively. Due to the high content of total solids and its negative effect of biogas production, the cattle dung and chicken manure were diluted by tap water to rich total solid $7.75 \%(\mathrm{w} / \mathrm{w})$. The compositions of mono and co-digestion of cattle dung and chicken manure under different operating temperatures are presented in Table (2).

\subsection{Digestion temperature}

The experimental work was carried out under horizontal $(\mathrm{H})$ and vertical (V) digester at $20 \pm 3{ }^{\circ} \mathrm{C}$ winter season (w), $29 \pm 3{ }^{\circ} \mathrm{C}$ summer season (s) and $38 \pm 1{ }^{\circ} \mathrm{C}$ heating treatment (h); (Hw, Hs, Hh, Vw, Vs and Vh; respectively) through digestion period of 60 days.

Temperature inside the digester at the beginning and end experiments are given in Table (3). It can be seen that there was difference between the initial and final temperature inside digester through the digestion period. 
Table (2): Compositions of cattle dung (CD) and chicken manure (CM).

\begin{tabular}{|c|c|c|c|c|c|c|}
\hline Substrate & $\begin{array}{c}\text { Temperature } \\
{ }^{\circ} \mathrm{C} \\
\end{array}$ & pH & $\begin{array}{c}\text { Total solids } \\
\text { (TS), \% }\end{array}$ & $\begin{array}{c}\text { Volatile solids } \\
\text { (VS), \% }\end{array}$ & $\begin{array}{c}\text { Total nitrogen, } \\
\%\end{array}$ & $\begin{array}{l}\mathrm{C}: \mathrm{N} \\
\text { ratio }\end{array}$ \\
\hline \multirow{3}{*}{$\begin{array}{c}\text { Cattle } \\
\text { dung } \\
(C D)\end{array}$} & $\begin{array}{c}20 \pm 3 \\
\text { (Winter) }\end{array}$ & 6.65 & 7.75 & 6.00 & 1.33 & 32.6 \\
\hline & $\begin{array}{c}29 \pm 3 \\
\text { (Summer) }\end{array}$ & 5.85 & 7.75 & 5.70 & 1.85 & 22.1 \\
\hline & $\begin{array}{c}38 \pm 1 \\
\text { (Heating) }\end{array}$ & 6.07 & 7.75 & 5.90 & 1.65 & 26.8 \\
\hline \multirow{3}{*}{$\begin{array}{c}\text { Chicken } \\
\text { manure } \\
(C M)\end{array}$} & $\begin{array}{c}20 \pm 3 \\
\text { (Winter) }\end{array}$ & 6.72 & 7.75 & 5.10 & 3.63 & 11.2 \\
\hline & $\begin{array}{c}29 \pm 3 \\
\text { (Summer) }\end{array}$ & 5.85 & 7.75 & 6.10 & 4.65 & 9.72 \\
\hline & $\begin{array}{c}38 \pm 1 \\
\text { (Heating) }\end{array}$ & 6.31 & 7.75 & 5.13 & 3.59 & 11.2 \\
\hline \multirow{3}{*}{$\begin{array}{c}\text { Mixture } \\
50 \% C D \\
\text { and } \\
50 \% C M \\
(w / w)\end{array}$} & $\begin{array}{c}20 \pm 3 \\
\text { (Winter) }\end{array}$ & 6.67 & 7.75 & 5.70 & 1.97 & 22.4 \\
\hline & $\begin{array}{c}29 \pm 3 \\
\text { (Summer) }\end{array}$ & 5.87 & 7.75 & 5.60 & 2.74 & 15.7 \\
\hline & $\begin{array}{c}38 \pm 1 \\
\text { (Heating) }\end{array}$ & 5.66 & 7.75 & 5.80 & 1.91 & 22.8 \\
\hline
\end{tabular}

Table (3): Temperature $\left({ }^{\circ} \mathrm{C}\right)$ through the continuous anaerobic mono and codigestion of $\mathrm{CD}$ and $\mathrm{CM}$ from the beginning to the end experimental.

\begin{tabular}{cccccccc}
\hline Exp. No. Initial & Final & Minimum & Maximum & Range & \multicolumn{2}{c}{ Mean } & Std. Deviation \\
\hline $\mathrm{H}_{\mathrm{w}}$ & 17.5 & 22.8 & 17.5 & 23.2 & 5.70 & 20.4 & 3.0702 \\
$\mathrm{H}_{\mathrm{s}}$ & 30.2 & 28.1 & 27.2 & 31.9 & 4.70 & 29.6 & 1.1724 \\
$\mathrm{H}_{\mathrm{h}}$ & 38.0 & 38.1 & 36.9 & 39.1 & 2.20 & 38.0 & 0.5765 \\
\hline $\mathrm{V}_{\mathrm{w}}$ & 17.3 & 22.8 & 17.3 & 23.1 & 5.80 & 20.2 & 3.0405 \\
$\mathrm{~V}_{\mathrm{s}}$ & 30.5 & 28.2 & 27.3 & 32.1 & 4.80 & 29.7 & 1.1797 \\
$\mathrm{~V}_{\mathrm{h}}$ & 38.1 & 38.3 & 37.1 & 39.2 & 2.10 & 38.2 & 0.4979 \\
\hline
\end{tabular}

\subsection{Analytical methods}

Released biogas volume was collected in gasholder and estimated by using the wetted displacement with calibrated scale in liter as shown in Fig. (1). The biogas composition was fractioned in a percentage i.e. methane and $\mathrm{CO}_{2}$ percentage using the potassium hydroxide 40\% (Abdel-Hadi, 2008). The TS, VS and total nitrogen (TN) levels were estimated according to standard 
methods (APHA, 1997). Organic carbon was calculated according to Black et al. (1965). Protein was calculated by multiplying total nitrogen by 6.25. Fat content was determined by Soxhlet apparatus (AOAC, 1990). Carbohydrate was calculated by the following formula:-

Carbohydrate $(\%)=100-($ ash $\%+$ protein $\%+$ fat $\%)$.

The temperature and $\mathrm{pH}$ value of the mixtures solution inside the bench-scale digesters were measured regularly every day using Jenway $\mathrm{pH}$ hand held meter model $370 \mathrm{pH} / \mathrm{mv}$.

\subsection{Experimental Procedure}

To study the effect of digester shape, horizontal and vertical digesters shape under three lab-scale experiments digestion temperatures; at winter, summer and heating were carried out from mono and co-digestion of cattle dung and chicken manure. Each experiment was 60 days (the first 10 days are start-up period). At the beginning of each experiment, each digester $(22 \mathrm{~L})$ was fed with $17 \mathrm{~kg}$ of fresh CD slurry $(7.75 \%)$ as a starter substrate. Then, $150 \mathrm{~g}$ of the influent substrates (CD, $\mathrm{CM}$ and $\mathrm{CD}+\mathrm{CM})$ at $7.75 \% \mathrm{TS}$ were added to the digesters then the feeding rate gradually increased to $680 \mathrm{~g}$ at the end of the start-up period and still to the end of experiment.

\section{RESULTS AND DISCUSSION}

During the first 10 days of the experimental period (60 days), the digesters were not unstable and methane contents in biogas were mostly less than $60 \%$, therefore data concerning the biogas and methane production were recorded from day 11 to day 60 .

\subsection{Biogas and methane production}

The cumulative biogas production of the horizontal and vertical digesters fed with $7.75 \%$ TS of mono-digestion $\mathrm{CD}, \mathrm{CM}$ and co-digestion $\mathrm{CD}$ and $\mathrm{CM}$ at an average temperature of digestion $20 \pm 6{ }^{\circ} \mathrm{C}$ (winter season), $29 \pm 3{ }^{\circ} \mathrm{C}$ (summer season) and $38 \pm 1^{\circ} \mathrm{C}$ (heating treatment) through the experimental period are shown in Fig (2). The maximum value of biogas production at the end of digestion period was 633 liters with $\mathrm{CD}+\mathrm{CM}$ under the horizontal digester through summer season. Meanwhile, the minimum value of biogas 
production recorded 96 liters with $\mathrm{CM}$ at the vertical digester through winter season.


Fig. (2): Cumulative biogas production from horizontal and vertical digesters fed with $\mathrm{CD}, \mathrm{CM}$ and $\mathrm{CD}+\mathrm{CM}$ at different conditions of digestion temperatures.

Average value of daily specific methane production in terms of VS added (L $\mathrm{kg}^{-1} \mathrm{VS} \mathrm{d}^{-1}$ ) is illustrated in Fig (3). It can be shown that the maximum value of daily specific methane production $238 \mathrm{~L} \mathrm{~kg}^{-1} \mathrm{VS} \mathrm{d}^{-1}$ was obtained with the horizontal digester fed by $\mathrm{CD}+\mathrm{CM}$ through summer season. Meanwhile, the minimum average value of daily specific methane production $27 \mathrm{~L} \mathrm{~kg}^{-1} \mathrm{VS} \mathrm{d}^{-1}$ was obtained with the vertical digester fed by $\mathrm{CM}$ through winter season. 


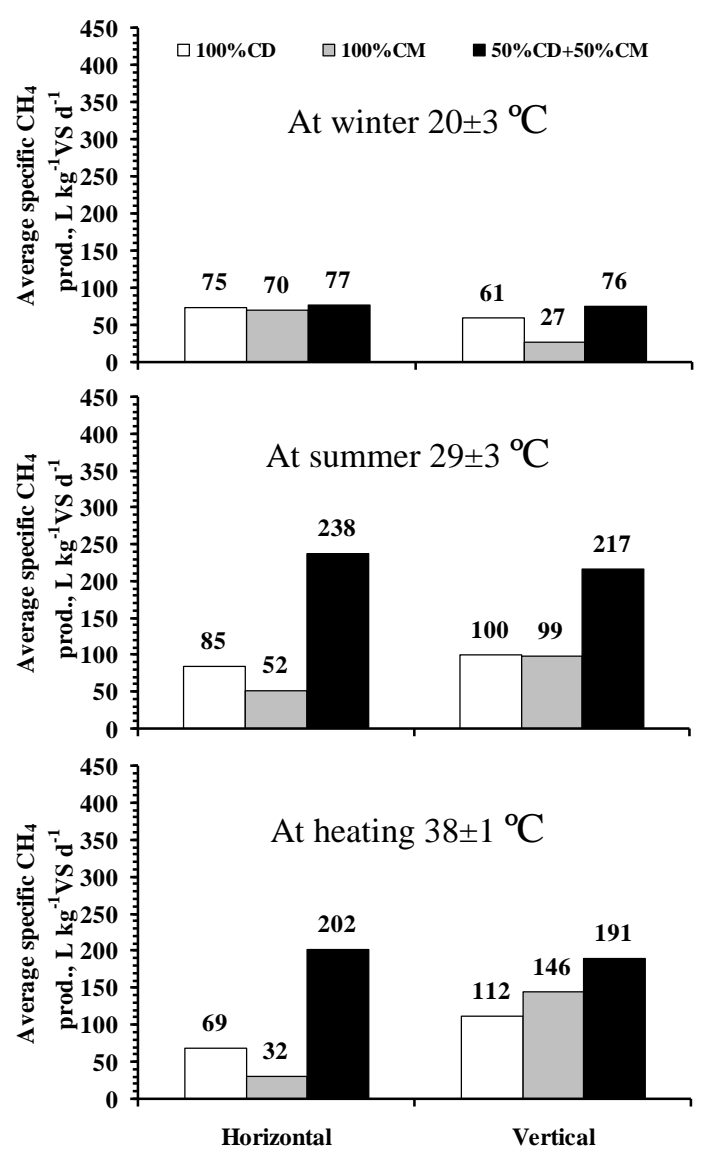

Fig. (3): Average of daily specific Methane production from horizontal and vertical digesters fed with $\mathrm{CD}, \mathrm{CM}$ and $\mathrm{CD}+\mathrm{CM}$ at different digestion temperatures.

The results show that the cumulative biogas and specific methane production from the various substrates under horizontal and vertical digester can be arranged in the following descending: $\mathrm{CD}+\mathrm{CM}>\mathrm{CD}>\mathrm{CM}$. This result is in partially agreement with that of Güngör-Demirci and Demirer (2004) who stated that, the cattle dung led to better performance than chicken manure in terms of methane production. The higher nitrogen content of chicken wastes as compared to manure from other farm animals make them difficult substrate 
for anaerobic digestion. On The other hand, digestion of chicken manure can produce toxic concentration of ammonia $\left(\mathrm{NH}_{3}\right)$ and hydrogen sulfide $\left(\mathrm{H}_{2} \mathrm{~S}\right)$.

Also, it is obvious that the highest cumulative biogas and specific methane produced were obtained from the horizontal digester loaded with $\mathrm{CD}+\mathrm{CM}$, while the lowest one was evolved from the same type of digester with $\mathrm{CM}$ alone. The data also indicate that the vertical digesters loaded with $\mathrm{CM}$ alone gave significantly higher amounts of cumulative biogas and specific methane production than the corresponding amounts from the horizontal ones. This may be attributed to the different surface area of the digested substrates in both digester types. In the horizontal digesters the surface area of the substrate is higher than that in the vertical ones. Consequently, the microorganisms inside the different digester types will be different in their types and activities.

The results also, showed that the cumulative biogas and specific methane production from the horizontal or vertical digesters loaded with $\mathrm{CD}+\mathrm{CM}$ at the tested digestion temperatures could be arranged in the following order: $29 \pm 3{ }^{\circ} \mathrm{C}>38 \pm 1^{\circ} \mathrm{C}>20 \pm 3{ }^{\circ} \mathrm{C}, \mathrm{CD}$ and $\mathrm{CM}$ in both digester types and $\mathrm{CD}$ in the horizontal digesters, the rates followed the order: $38 \pm 1{ }^{\circ} \mathrm{C}>29 \pm 3{ }^{\circ} \mathrm{C}>$ $20 \pm 3{ }^{\circ} \mathrm{C}$. This may be due to satisfactory gas production takes place in the mesophilic range, between 25 to $30^{\circ} \mathrm{C}$ (FAO, 1997).

\subsection{Methane and carbon dioxide concentration}

Fig. (4) show that the methane concentrations (by volume) in biogas in all experiments varied considerably depending on the substrate and digester type as well as the digestion temperature. The digestion time lasted to reach $60 \%$ methane (volumetric basis) in the biogas (a sign of healthy digestion) was found in the three experiments to increase following the order: $\mathrm{CM}>\mathrm{CD}+\mathrm{CM}>\mathrm{CD}$. Explanation of this result is based upon the fact that $\mathrm{CM}$ is generally regarded as a difficult substrate for anaerobic digestion mainly because of its typically high proteins and lipids contain (Table 1). Protein degradation produce ammonia, the 
unionized from, which is inhibitory to anaerobic microorganisms in high concentrations. Lipids, on the other hand, may cause problems in anaerobic digestion because of their tendency to from floating scum and accumulated long chain fatty acids (Salminen and Rintala, 2002 a, $\mathbf{b}$ ). It also increased with decreasing the digestion temperature. On the other hand, it was mostly longer in the horizontal digesters than the vertical ones.

As shown in the Fig. (4), the averages of methane concentrations from the vertical digesters fed with $\mathrm{CD}, \mathrm{CM}$ and $\mathrm{CD}+\mathrm{CM}$ at the winter were 58.6, 50.4 and 59.7\%, respectively, at the summer were 61.3, 63.6 and $68.1 \%$, respectively and at the heating were $63.1,61.6$ and $66.9 \%$ for the abovementioned substrates slurries, respectively. The corresponding averages of methane concentrations from the horizontal digesters fed with $\mathrm{CD}, \mathrm{CM}$ and $\mathrm{CD}+\mathrm{CM}$ at the winter were $60.0,62.3$ and $49.3 \%$, respectively, at the summer were 61.1, 50.2 and $66.9 \%$, respectively and at the heating were 58.1, 42.0 and $65.1 \%$, respectively. However, the average methane contents in biogas evolved from the various substrates in the vertical digesters and from $\mathrm{CD}+\mathrm{CM}$ in the horizontal ones at $20 \pm 3$ ${ }^{\circ} \mathrm{C}$ were less than $60 \%$ (49.3-59.7\%) indicating that the biogas produced from most treatments in the winter experiment was low quality in terms of energy production. On the other hand, methane contents in biogas evolved from the horizontal digesters loaded with CM decreased with increasing the digestion temperature whereas they were 62.3, 50.2 and $42.0 \%$ for $20 \pm 3{ }^{\circ} \mathrm{C}, 29 \pm 3{ }^{\circ} \mathrm{C}$ and $38 \pm 1{ }^{\circ} \mathrm{C}$, respectively. This result confirmed the inhibitory effect of ammonia concentrations which increased with raising digestion temperature especially in the horizontal digesters which have a higher surface area compared to the vertical digesters. 


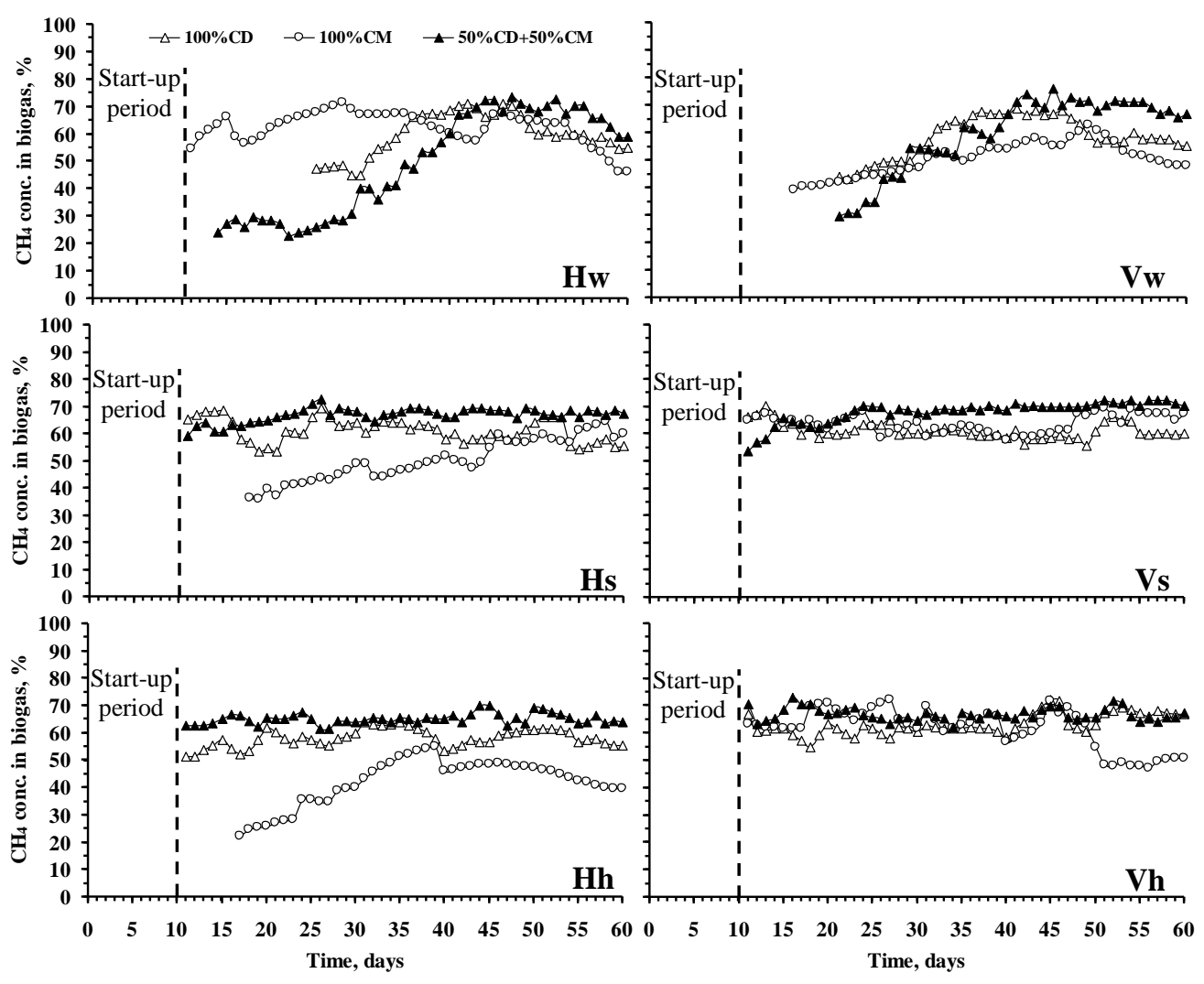

Fig. (4): Methane concentration in biogas produced from horizontal and vertical digesters fed with $\mathrm{CD}, \mathrm{CM}$ and $\mathrm{CD}+\mathrm{CM}$ under different digestion temperatures.

The $\mathrm{CO}_{2}$ concentrations in biogas produced from the various substrates in both digester shape at different digestion temperatures as shown in the Fig. (5). The averages of $\mathrm{CO}_{2}$ concentrations from the vertical digesters fed with $\mathrm{CD}, \mathrm{CM}$ and $\mathrm{CD}+\mathrm{CM}$ at the winter were 38.4, 46.6 and $37.3 \%$, respectively, at the summer were $35.7,33.4$ and $28.9 \%$, respectively and at the heating were $33.9,35.4$ and $30.1 \%$ for the above-named substrates, respectively. The corresponding averages of $\mathrm{CO}_{2}$ concentrations from the horizontal digesters fed with $\mathrm{CD}, \mathrm{CM}$ and $\mathrm{CD}+\mathrm{CM}$ at the winter were $37.0,34.7$ and $47.7 \%$, respectively, at the summer were $35.9,46.8$ and $30.1 \%$, respectively and at the heating were $38.9,55.0$ and $31.9 \%$, respectively. 



Fig. (5): Carbon dioxide concentration in biogas produced from horizontal and vertical digesters fed with $C D, C M$ and $\mathrm{CD}+\mathrm{CM}$ under different digestion temperatures.

\section{3. $\mathrm{pH}$ value}

The average $\mathrm{pH}$ values of the digested substrates for different treatments are varied as shown in Fig (6). At $38 \pm 1{ }^{\circ} \mathrm{C}$ and $29 \pm 3{ }^{\circ} \mathrm{C}$, the average $\mathrm{pH}$ values of the digested substrates were found to follow the orders: $\mathrm{CD}+\mathrm{CM}>\mathrm{CD}>\mathrm{CM}$ for the horizontal digesters and $\mathrm{CD}+\mathrm{CM}>\mathrm{CM}>$ $\mathrm{CD}$ for the vertical ones. The average $\mathrm{pH}$ values ranges in the digested substrates at $29 \pm 3{ }^{\circ} \mathrm{C}$ and $38 \pm 1{ }^{\circ} \mathrm{C}$ were $5.99-7.47$ for the horizontal digesters and $6.42-7.46$ for the vertical ones. At $20 \pm 3{ }^{\circ} \mathrm{C}$, the average $\mathrm{pH}$ values in both digester types ranged between 6.64 and 6.95. The average $\mathrm{pH}$ values for $\mathrm{CD}+\mathrm{CM}$ in both digester types were found to increase with increasing the digestion temperature. 


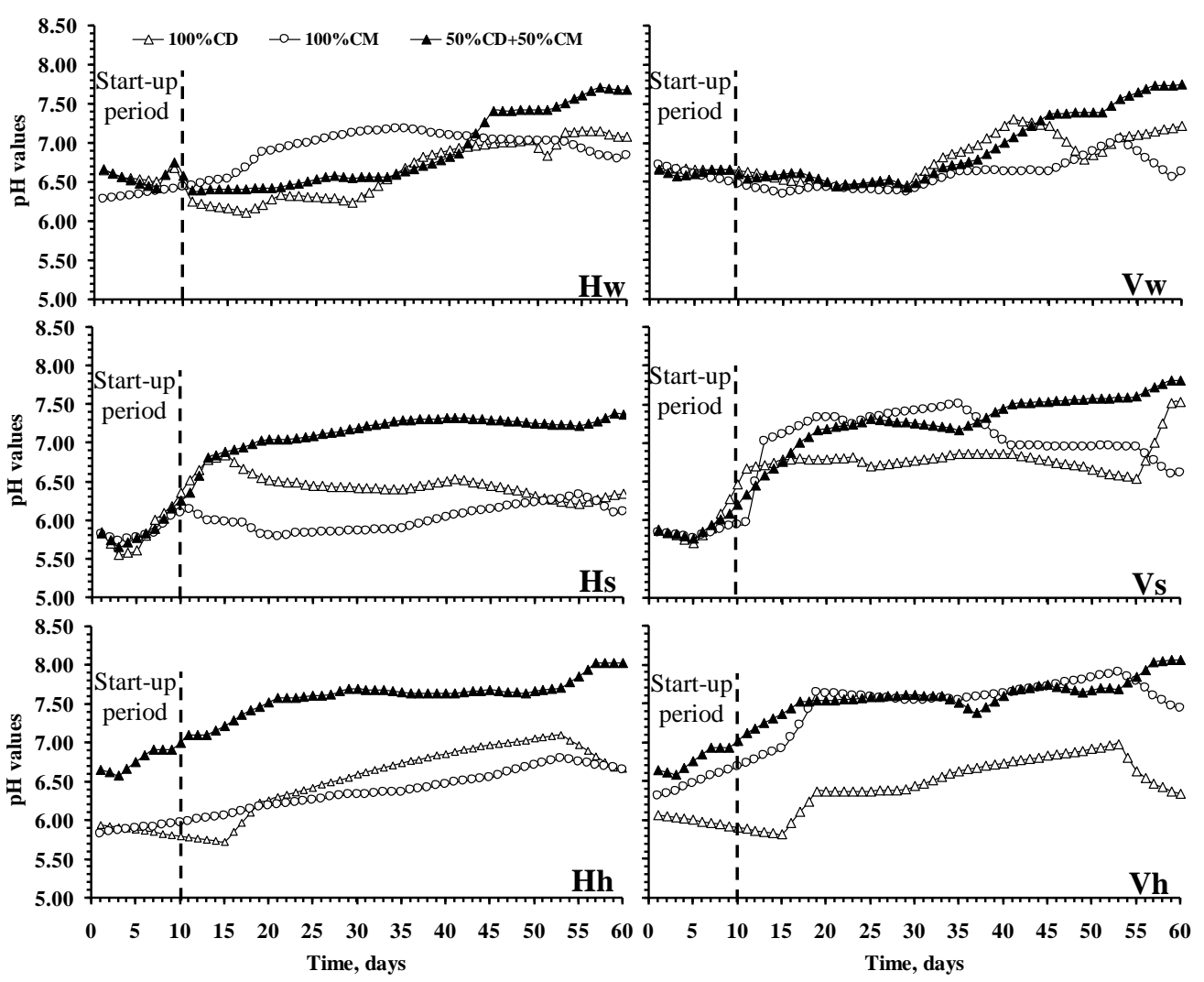

Fig. (6): Values of $\mathrm{pH}$ in horizontal and vertical digesters fed with $\mathrm{CD}, \mathrm{CM}$ and $\mathrm{CD}+\mathrm{CM}$ under different digestion temperatures.

Table (4) illustrated the average values of degradation, carbon dioxide, methane percent, $\mathrm{pH}$ value and $\mathrm{C}: \mathrm{N}$ ratio for different treatments under study. At the vertical digesters when temperature increased degradation percent increased from three substrates, $\mathrm{pH}$ value, the carbon dioxide decreased and methane percent increased from $\mathrm{CD}$, meanwhile from $\mathrm{CM}$ and $\mathrm{CD}+\mathrm{CM}$ the highest methane percent were 63.6 and $68.1 \%$ at summer, respectively and the lowest methane percent were 50.4 and $59.7 \%$ at winter, respectively. 
Table (4): The average value of the degradation, carbon dioxide, methane percent, $\mathrm{pH}$ value and $\mathrm{C}: \mathrm{N}$ ratio under different treatments.

\begin{tabular}{|c|c|c|c|c|c|c|c|c|}
\hline \multirow{2}{*}{$\begin{array}{l}\text { Digester } \\
\text { shape }\end{array}$} & \multirow[t]{2}{*}{ Parameters } & \multicolumn{2}{|c|}{$\begin{array}{c}\text { Winter } \\
\underline{20 \pm 3{ }^{\circ} \mathrm{C}} \\
\end{array}$} & \multicolumn{2}{|c|}{$\begin{array}{l}\text { Summer } \\
\underline{29 \pm 3^{\circ} \mathrm{C}}\end{array}$} & \multicolumn{3}{|c|}{$\begin{array}{l}\text { Heating } \\
38 \pm 1^{\circ} \mathrm{C} \\
\end{array}$} \\
\hline & & CD CM & $\mathrm{CD}+\mathrm{Cl}$ & M CD CM & $\mathrm{CD}+\mathrm{CM}$ & I CD & CM & $\mathrm{CD}+\mathrm{CM}$ \\
\hline \multirow{5}{*}{ Vertical } & Degradation, \% & 13.56 .67 & 12.4 & 31. 25.1 & 25.8 & 35.6 & 26.3 & 36.1 \\
\hline & Carbon dioxide, & 38.746 .8 & 36.5 & 35. 34.4 & 28.9 & 33.9 & 35.4 & 30.1 \\
\hline & Methane, \% & 58.650 .4 & 59.7 & 61.63 .6 & 68.1 & 63.1 & 61.6 & 66.9 \\
\hline & pH value & 6.806 .95 & 6.91 & 6.66 .8 & 7.05 & 6.42 & 7.33 & 7.46 \\
\hline & $\mathrm{C}: \mathrm{N}$ ratio & 28.219 .6 & 23.8 & 26. 15.6 & 18.9 & 23.7 & 19.0 & 19.9 \\
\hline \multirow{5}{*}{ Horizontal } & Degradation, \% & 17.36 .88 & 13.2 & 45. 24.3 & 48.0 & 31.0 & 23.6 & 44.0 \\
\hline & Carbon dioxide, & 37.634 .7 & 48.6 & 35.948 .5 & 30.1 & 38.9 & 56.6 & 31.9 \\
\hline & Methane, \% & 59.962 .3 & 49.3 & 61.50 .2 & 66.9 & 58.1 & 40.0 & 65.1 \\
\hline & pH value & 6.646 .84 & 6.86 & 6.35 .99 & 6.92 & 6.48 & 6.32 & 7.47 \\
\hline & $\mathrm{C}: \mathrm{N}$ ratio & 28. 18.5 & 22.7 & 22. 18.6 & 18.7 & 22.8 & 20.1 & 19.3 \\
\hline
\end{tabular}

On the other hand, the highest degradation percent were 45.9 and $48.0 \%$ under the horizontal digesters from $\mathrm{CD}$ and $\mathrm{CD}+\mathrm{CM}$ at summer season, respectively and the highest methane percent were 61.1 and $66.9 \%$ at summer season, respectively, meanwhile the lowest degradation and methane percent observed from co-digestion of $\mathrm{CD}+\mathrm{CM}$ were 13.2 and $49.3 \%$ at winter season, respectively. Meanwhile methane contents in biogas evolved from the horizontal digesters loaded with CM decreased with increasing the digestion temperature. Generally, when the C:N ratio decreased the methane percent increased at all treatments.

\section{CONCLUSION}

\section{Concluding remarks based on the obtained date are as follows:}

- The cumulative biogas and specific methane production from all treatments in all experiments, except for those of the vertical digesters at (heating treatment) $38 \pm 1{ }^{\circ} \mathrm{C}$, were found to follow the order: 
$\mathrm{CD}+\mathrm{CM}>\mathrm{CD}>\mathrm{CM}$. However, the order was $\mathrm{CD}+\mathrm{CM}>\mathrm{CM}>\mathrm{CD}$ for the vertical digesters treatments at (heating treatment) $38 \pm 1^{\circ} \mathrm{C}$.

- The highest average methane content of $68.1 \%$ (by volume) in biogas was observed in the vertical digesters fed with $\mathrm{CD}+\mathrm{CM}$ at digestion temperature (summer season) $29 \pm 3{ }^{\circ} \mathrm{C}$. On the contrary, the lowest average methane content of $42.0 \%$ was found in the horizontal digesters loaded with $\mathrm{CM}$ alone at (heating treatment) $38 \pm 1{ }^{\circ} \mathrm{C}$.

- The highest average specific methane production rates of $238 \mathrm{~L} \mathrm{~kg}^{-1} \mathrm{VS}$ added per day were obtained from the horizontal digesters fed with $\mathrm{CD}+\mathrm{CM}$ at (summer season) $29 \pm 3{ }^{\circ} \mathrm{C}$, while the lowest rates of $32 \mathrm{~L} \mathrm{~kg}^{-1} \mathrm{VS}$ added per day were observed in the horizontal digesters loaded with $\mathrm{CM}$ alone at (heating treatment) $38 \pm 1^{\circ} \mathrm{C}$, respectively.

- The biogas produced from most treatments in the winter experiment was low quality in terms of energy production.

- Methane contents in biogas evolved from the horizontal digesters loaded with $\mathrm{CM}$ decreased with increasing the digestion temperature.

\section{REFERENCES}

Abdel-Hadi, M. A. (2008): A simple apparatus for biogas quality determination. Misr J. Agric. Eng., 25(3): 1055-1066.

Angelidaki, I. and Ahring, B. K. (1993): Thermophilic anaerobic digestion of livestock waste: the effect of ammonia. Appl. Microbiol. Biotechnol., 38(4): 560-564.

AOAC, Association of Official Analytical Chemists (1990): Official Methods of Analysis. $15^{\text {th }}$ Edition, Washington, DC., USA.

APHA, American Public Health Association (1997): Standard Methods for the Examination of Water and Wastewater. $19^{\text {th }}$ ed., Washington, DC.

Bardiya, N. and Gaur, A. C. (1997): Effects of carbon and nitrogen ratio on rice straw biomethanation. J. of Rural Energy, 4(1-4): 1-16.

Black, C. A.; Evans, D. O.; Ensminger, L. E.; White, J. L.; Clark, F. C. and Dineuer (1965): Methods of soil analysis. II-chemical and microbiological properties. American Society of Agronomy Inc., Madison, Wisconsin, USA. 
FAO, Food and Agriculture organization (1997): A System Approach to Biogas Technology: (from Biogas Technology: A training manual for extension) (FAO/CMS, 1996), Sustainable Development Department (SD dimensions), SD: Environment: Energy and Environ. Technol., posted June 1997.

FAO, Food and Agriculture organization (2001): Production yearbook, Food and Agricultural Organisation of the United Nations. Rome, Italy.

GTZ, Gesellschaft für Technische Zusammenarbeit (1999): Biogas Digest: (Volume II. Biogas - Application and Product Development) GTZ-GATE. Eschborn, Germany.

Güngör-Demirci, G. and Demirer, G. N. (2004): Effect of initial COD concentration, nutrient addition, temperature and microbial acclimation on anaerobic treatability of broiler and cattle manure. Bioresour. Technol., 93: 109-117.

Hartmann, H.; Angelidaki, I. and Ahring, B. K. (2000): Increase of anaerobic degradation of particulate organic matter in full-scale biogas plants by mechanical maceration. Water Sci. Technol., 41: 145-153.

Lusk, P. (1999): Latest Progress in Anaerobic Digestion. BioCycle Magazine, Volume 40, Number 7, USA.

Nielsen, H. B. (2006): Control Parameters for Understanding and Preventing Process Imbalances in Biogas Plants: Emphasis on VFA Dynamics. Ph.D. dissertation, BioCentrum-DTU, Technical University of Denmark, Denmark.

Salminen, E. A. and Rintala, J. A. (2002 $\mathrm{a})$ : Anaerobic digestion of organic solid poultry slaughterhouse waste-a review. Bioresour. Technol. 83, 13-26.

Salminen, E. A. and Rintala, J. A. (2002 $\mathrm{b})$ : Semi-continuous anaerobic digestion of solid poultry slaughterhouse waste: effect of hydraulic retention time and loading, Water Res., 36: 3175-3182. 
Sanchez, E.; Borja, R.; Weiland, P.; Travieso, L. and MartIn, A. (2000): Effect of temperature and $\mathrm{pH}$ on the kinetics of methane production, organic nitrogen and phosphorus removal in the batch anaerobic digestion of cattle manure. Bioprocess Engineering, 22: 247-252.

Tafdrup, S. (1995): Viable energy production and waste recycling from anaerobic digestion of manure and other biomass. Biomass and Bioenergy, 9(1-5): 303-314.

Weiland, P. (2000): Anaerobic waste digestion in Germany-Status and recent developments. Biodegradation, 11: 415-421.

\section{Zennaki, B. Z.; Zadi, A.; Lamini, H.; Aubinear, M. and Boulif, M.} (1996): Methane Fermentation of cattle manure: effects of HRT, temperature and substrate concentration. Tropicultural 14(4): 134-140.



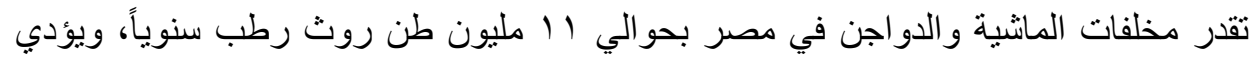

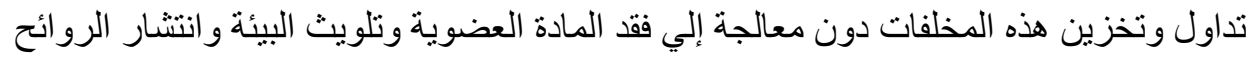


العضوية الغاز الحيوي (البيوجاز) وهو من أهم مصادر الطاقة خاصة في المناطق الريفية، وسماد متحلل غنى في محتو اة من المادة العضوية العناز أجريت التجارب في معمل البيوجاز بقسم الهندسة الزر اعية ـ مزر عة كلية الزئة الزراعة ـ جامعة قناة

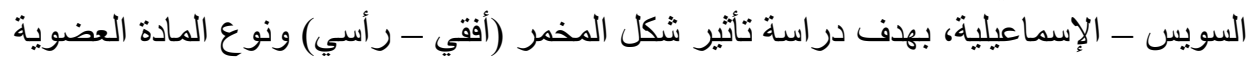



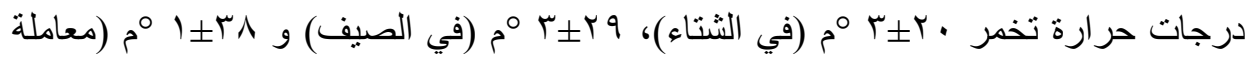





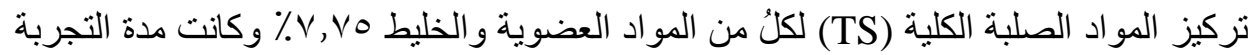

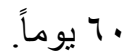

"أستاذ، أستاذ مساعد، معيد ـ قسم الهندسة الزر اعية ـ كلية الزر اعة - جامعة قناة السويس.

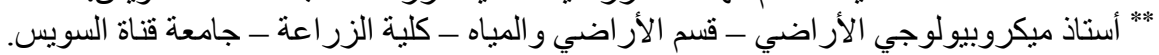




\section{وقد توصلت الدراسة اللى النتائج التالية:-}

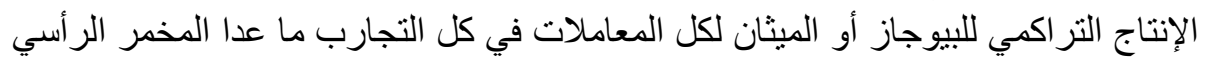

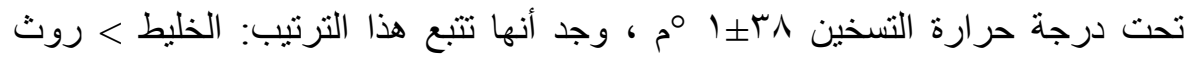



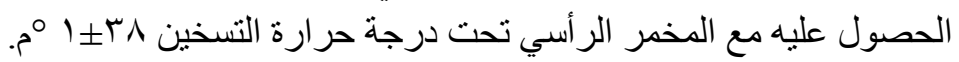



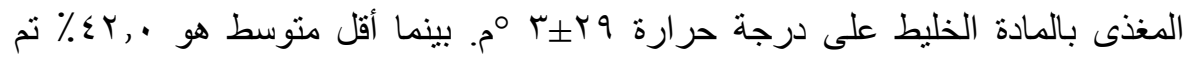

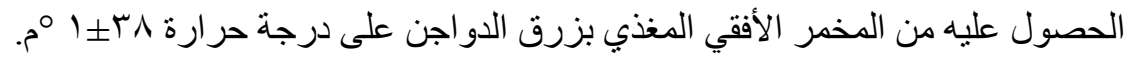

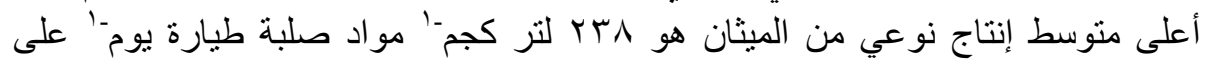

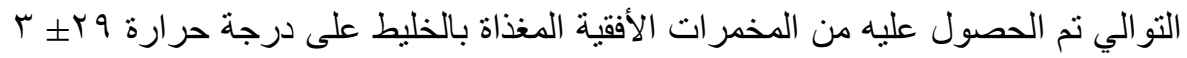

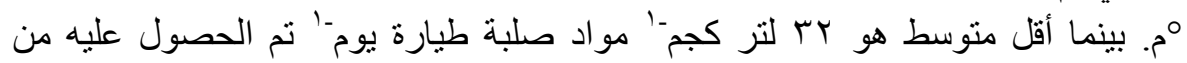

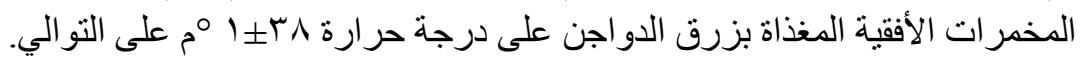



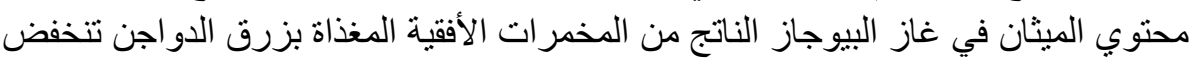



